\title{
Thoughts on the Development of Talent Strategy System in High-quality Teaching and Research Universities with Distinctive Features
}

\author{
A Case Study of Jiangsu Nantong University of China
}

\author{
Lu Cheng \\ Personnel Department \\ Nantong University \\ Nantong, Jiangsu, China, 226019
}

\begin{abstract}
It is the top priority for Jiangsu Nantong University to build a talent team with high quality which is the key to raise school-running level as well. Positioning and exploration of development policies and new thinking on the construction of talent strategy system have been made. They are based on investing in and cultivation to build a threedimensional, overall and scientific system.
\end{abstract}

Keywords—comprehensive university; talent strategy; system construction

\section{INTRODUCTION}

According to Several Opinions of the Ministry of Education on Improving the Quality of Higher Education in an all-round way in 2012(Hereinafter referred to as Opinions), it was advocated that colleges and universities should have their own characteristics. "Schools should make positioning, plan, talents' training and setting of majors in accordance with their history, region and resource reserves."

${ }^{[1]}$ As the competition of higher education is becoming fiercer, it is well acknowledged that talent is the key to win. Talent developing strategy is taken by all the universities in China. On this condition, only by following the principle of education and talents and carrying out policies suitable to itself, we can a university build an energetic talent team with high quality, proper structure. In this way it can enjoy rapid development and stand out from competition in the end. This paper is based on the real condition in Nantong University. It is about the construction of talent strategy system.

\section{COMPARED UNIVERSITY SHOULD BE MADE TO THE CONSTRUCTION OF TALENT STRATEGY SYSTEM}

As a social organization, university must have it goal. What's more, the construction of its department, staff structure and operation mode must be based on its goal. In

Fund project: Research project on Jiangsu province higher education reform "The construction of teachers developing center in regional comprehensive universities and the research and practice of the training of young teachers" (2013JSJG033) . 2. 2013 teaching reform project in Nantong University "talents project and teachers' development based on the thoughts of education and teaching reform". the Second Party Congress of this university, we simplified the development as "Yangtze-crossing development, transition development, connotation development and characterized development". Meanwhile, we made the construction of a high-quality teaching and research university our goal which reflected the positioning of our university in the classification system of China's universities.

At present, there are four classification methods on China's universities. First, according to research scale, there are research-oriented universities, teaching and research universities and teaching-oriented universities. Second, according their school-running quality, there are first-class universities, high-level universities and other universities. Third, according t their subjects, there are comprehensive universities, art and science universities, engineering universities and agricultural and forestry universities. Then, Grouped by Administrative Relationship, there are universities under the direct administration of government departments or a province and regional universities. Among the four classifications, we will realize our goal of the first upon the complement of Doctor Station. The third one is about natural features. The last is based on institution and region. However, to fulfill our goal for the second, we need to make arduous efforts. What's more, if only it is with distinctive features, which is the internal quality of regional university, can it become a university with high quality. The fundamental way for regional universities to realize sustainable development is to make school-running with their own characteristics and raise their core competitiveness. School-running characteristics that are competitive and innovative are the most distinctive features for a university. They can also help it maintain its competitiveness. [2] To build a high-quality university with distinctive features, we should make other universities for comparison. These compared universities can be chosen based on the data from China's universities ranking according to their overall quality and region.

As a result of research on evaluation system, the universities ranking might not be able to reflect the whole condition of universities. However, though suffering from 
controversy, it can reflect the running quality and social impact of these universities to some extent. Expect for universities of "985 projects" and "211 projects" in Wu Shuliang Ranking of Universities in China, the first 200 regional universities in their comprehensive strength are selected as the comparison to our university. In order to make it objective and comparative, there are also rankings of these universities in Chinese Alumni Net.

TABLE I. RANKINGS OF UNIVERSITIES

\begin{tabular}{|c|c|c|}
\hline $\begin{array}{c}\text { Ranking in Wu } \\
\text { Shulian }\end{array}$ & University & $\begin{array}{c}\text { Ranking in Alumni } \\
\text { Net }\end{array}$ \\
\hline 63 & Jiangsu University & 117 \\
\hline 68 & Yangzhou University & 111 \\
\hline 78 & Shanxi University & 75 \\
\hline 89 & Heilongjiang University & 104 \\
\hline 91 & Ningbo University & 161 \\
\hline 141 & Nantong University & 229 \\
\hline 146 & Hubei University & 131 \\
\hline 147 & Jinan University & 219 \\
\hline 155 & Guangzhou University & 191 \\
\hline 196 & Yangtze University & 199 \\
\hline
\end{tabular}

Among the universities in Table 1, Jinan University and Nantong University became doctor degree granting institutions in 2013, rankings of these two universities fluctuated as well. In $\mathrm{Wu}$ Shulian Ranking of Universities, Nantong University was 6 universities ahead, while in Ranking in Alumni Net, it was exceeded by Jinan University by 10 . Being in the same level as Nantong University, it can serve as a compared university.

Seeing from regions, there are universities like Yangzhou University, Jiangsu University, Ningbo University and Nantong University in Yangtze River Delta. Among them, Yangzhou University, Jiangsu University and Nantong University are in Jiangsu province. Thus, Yangzhou University and Jiangsu University can be compared universities of Nantong University. To catch up with them, we still have a long way to go.

\section{FURTHER STUDY ON THE TALENTS' CONDITIONS AND POLICIES OF COMPARED UNIVERSITIES SHOULD BE MADE}

The talents' conditions and policies of compared universities can serve as an example for the construction of our school. For universities, the scale of talents and teachers is determined by their students scale, scientific research scale and school-running quality.

\section{A. Basic Situations of Compared Universities}

Being same as Nantong University, Yangzhou University, Jiangsu University and Jinan University were comprehensive universities found or merged after reform and opening-up. Among them, Yangzhou University was merged in 1992, which was the earliest. Jiangsu University and Jinan University were found in 2001, 3 years earlier than Nantong University. Table 2 is about the basic situations of these four universities in 2014. The following tables are based on the data from their school website:
TABLE II. BASIC SITUATIONS OF SCHOOL-RUNNING IN 2014

\begin{tabular}{|c|c|c|c|c|c|}
\hline \multirow{2}{*}{$\begin{array}{l}\text { Universit } \\
\mathbf{y}\end{array}$} & $\begin{array}{c}\text { School- } \\
\text { runnin } \\
\text { g level }\end{array}$ & $\begin{array}{c}\text { Number } \\
\text { of } \\
\text { undergr } \\
\text { aduate } \\
\text { majors }\end{array}$ & $\begin{array}{c}\text { Undergradu } \\
\text { ate }\end{array}$ & Master & Doctor \\
\hline $\begin{array}{c}\text { Yangzhou } \\
\text { University }\end{array}$ & $\begin{array}{c}\text { Doctor's } \\
\text { Degree }\end{array}$ & 112 & 33000 & 9000 \\
\hline $\begin{array}{c}\text { Jiangsu } \\
\text { University }\end{array}$ & $\begin{array}{c}\text { Doctor's } \\
\text { Degree }\end{array}$ & 87 & 42000 & 9400 \\
\hline $\begin{array}{c}\text { Jinan } \\
\text { University }\end{array}$ & $\begin{array}{c}\text { Doctor's } \\
\text { Degree }\end{array}$ & 89 & 30000 & 1500 \\
\hline $\begin{array}{c}\text { Nantong } \\
\text { University }\end{array}$ & $\begin{array}{c}\text { Doctor's } \\
\text { Degree }\end{array}$ & 94 & 35000 & 1802 \\
\hline
\end{tabular}

TABLE III. SCALE OF SCIENTIFIC RESEARCH IN COUNTRY LEVEL (2013-2014)

\begin{tabular}{|c|c|c|c|c|}
\hline \multirow{2}{*}{ University } & \multicolumn{4}{|c|}{$\begin{array}{c}\text { Scale of Scientific Research in Country } \\
\text { Level }\end{array}$} \\
\cline { 2 - 5 } & $\begin{array}{c}\text { Natural science } \\
\text { Fund }\end{array}$ & \multicolumn{2}{c|}{ Social Science Fund } \\
\cline { 2 - 5 } & In 2012 & In 2013 & In 2014 & In 2015 \\
\hline Yangzhou University & 90 & 111 & 4 & 12 \\
\hline Jiangsu University & 134 & 142 & 4 & 4 \\
\hline Jinan University & 41 & 45 & 8 & 18 \\
\hline Nantong University & 68 & 81 & 4 & 8 \\
\hline
\end{tabular}

According to Table 2, the school-running scale of these two universities did not vary much in undergraduate students, while things became different in the scale of postgraduate students. It was nearly same as Jinan University, while it was totally different from Yangzhou University and Jiangsu University. From the vague number of postgraduates in Yangzhou University and Jiangsu University, we could know that they did not have large scales of doctoral students. According to the data of scientific research scale from Table 3, Natural science Fund in Nantong University was more than that in Jinan University, but it was still far less than that in Yangzhou University and Jiangsu University which was nearly twice of that in Nantong University.

\section{B. Talents' Conditions of Compared Universities}

1) Overall scale of teachers and other staffs. The overall scale of teachers and other staffs in these four universities can reflect their investment for human resources and their development conditions. Their internal structures can make us know the upgrading of human resources. Here in Table 4, we can see the overall scale of teachers and staffs in these universities in 2014. 
TABLE IV. OVERALL SCALE OF TEACHERS AND OTHER STAFFS IN 2014

\begin{tabular}{|c|c|c|c|c|c|}
\hline University & $\begin{array}{c}\text { Number } \\
\text { of } \\
\text { teachers } \\
\text { and } \\
\text { other } \\
\text { staffs }\end{array}$ & $\begin{array}{c}\text { Number } \\
\text { of full- } \\
\text { time } \\
\text { teachers }\end{array}$ & $\begin{array}{c}\text { Number } \\
\text { of } \\
\text { professors }\end{array}$ & $\begin{array}{c}\text { Number } \\
\text { of } \\
\text { associate } \\
\text { professors }\end{array}$ & $\begin{array}{c}\text { Number } \\
\text { of } \\
\text { doctoral } \\
\text { students }\end{array}$ \\
\hline $\begin{array}{c}\text { Yangzhou } \\
\text { University }\end{array}$ & 3800 & 2100 & \multicolumn{2}{|c|}{1200} & 533 \\
\hline $\begin{array}{c}\text { Jiangsu } \\
\text { University }\end{array}$ & 4800 & 2500 & 420 & 810 & 1153 \\
\hline $\begin{array}{c}\text { Jinan } \\
\text { University }\end{array}$ & 4000 & 2066 & 298 & 666 & 711 \\
\hline $\begin{array}{c}\text { Nantong } \\
\text { University }\end{array}$ & 3100 & 2200 & 291 & 700 & 535 \\
\hline
\end{tabular}

According to Table 4, for universities with nearly the same number of undergraduate students, the one that has a higher school-running level can enjoy a lager scale of scientific research and more teachers and staffs. That is to say, the development of universities has interaction with team scale.

2) Basic condition of high-level talents. In social level, universities are the platforms for high-level talents. Thus, the competition of talents also means the competition of highlevel talents in scale and number. The basic conditions of high-level talents of these four universities can be seen in Table 5:

From Table 5, we can know that all the universities have attached great importance to the training and recruitment of academicians. Some even recruit academicians from other universities. Only two universities have academicians. Liu Xiufan who is an academician in Yangzhou University was born in Jiangsu province. The only academician of ophthalmology in China named Xie Lixin was appointed as honorary director of academic board and dean of College of Medicine and Life Science. Appointment like this has more meaning than double-employment. Jiangsu University did very well in the construction of high-level talents of other kinds.

3) Talent policies of compared universities. All colleges and universities have attached great importance to the construction of talent teams especially those for high-level talents. Yangzhou University planed to spend a million yuan recruiting academician early in 2001, but it turned out to be a failure. Finally, Liu Xiufan became an academician successfully. "Rules for the Implementation of Top Talents' Training Project in Jiangsu University and Rules for recruitment" and "Post-setting of Distinguished Professor in Jiangsu University" were carried out by this university to help the recruitment and training of talents. "Opinions for the Implementation of Recruiting High-level Talents through "Double Recruitment" in Jinan University" were carried out by Jinan University. Foreign experts were employed as academic pacemakers here. "Attracting and gathering talents by talents there" It was the so called snowball effect.

\section{WE NEED TO ESTABLISH A SCIENTIFIC AND EFFECTIVE TALENT STRATEGy SySTEM IN AN ALL-ROUND WAY}

To make our university a high-quality teaching and research universities with distinctive features, we need to pay attention to and study on the developing of compared universities, especially the formulation and implementation of talent developing strategies. In this way, we can make adjustment of our own development policies. The condition and policies of talents in compared universities can provide great enlightenment on the adjustment of our own development polices and on the establishment of talent strategy system. We need to focus on the recruitment and training of talents to establish a three-dimensional, comprehensive and scientific talent strategy system.

TABLE V. BASIC CONDITIONS OF High-LEVEL TALENTS (2014)

\begin{tabular}{|c|c|c|c|c|c|c|c|c|}
\hline University & Academician & $\begin{array}{l}\text { Double-employed } \\
\text { Academician }\end{array}$ & $\begin{array}{l}\text { Distinguished } \\
\text { Young Scholars }\end{array}$ & $\begin{array}{l}\text { the } \\
\text { Thousand } \\
\text { Talents } \\
\text { Plan }\end{array}$ & $\begin{array}{c}\text { Top } \\
\text { Talent }\end{array}$ & $\begin{array}{c}\text { Changjiang } \\
\text { Scholars }\end{array}$ & $\begin{array}{c}\text { Thousand } \\
\text { Young } \\
\text { Talent }\end{array}$ & $\begin{array}{l}\text { Great } \\
\text { Talent }\end{array}$ \\
\hline $\begin{array}{l}\text { Yangzhou } \\
\text { University }\end{array}$ & 1 & & 1 & & 3 & & & 4 \\
\hline $\begin{array}{l}\text { Jiangsu } \\
\text { University }\end{array}$ & & 7 & 2 & 1 & 8 & 1 & 1 & 2 \\
\hline $\begin{array}{c}\text { Jinan } \\
\text { University }\end{array}$ & 2 & & & & & & & 6 \\
\hline $\begin{array}{l}\text { Nantong } \\
\text { University }\end{array}$ & & 5 & 1 & & & & & 2 \\
\hline
\end{tabular}

Note: Distinguished Young Scholars refers to those who have won the National Science Fund for Distinguished Young Scholars (NSFDYS); the Thousand Talents Plan refers to Recruitment Program of Global Experts; Top Talent refers to state class talents selected by New Century Talents Project; Thousand Young Talent refers to Recruitment Program for Young Professionals; Great Talent refers to those that are the winner of New Century Talent Supporting Project, the second level of High-level creative Talents Plan by Ministry of Education. 


\section{A. The Recruitment of Overseas Talents should be Strengthened}

Only few colleges and universities in China can recruit full-time academicians. In this way, we need to focus on the recruitment of overseas talents, mainly those doctors and assistant professors in first-class universities. It is also one of the important ways to promote international education. Our university should make full use of the relevant talent policies in Nantong city and Jiangsu province to recruit overseas high-level talents.

\section{B. Flexible Polices should be Adopted for the Recruitment of Talents}

For the great talents, we may have no condition to employ them. So it is important to use instead of employing. For academicians, Distinguished Young Scholars , Changjiang Scholars, Distinguished Professors, personnel with senior technical titles or doctorates and Doctoral Tutors, we should not just thinking about employing them. It is good, if they can do lectures in our university. Based on the condition of our development, we need to strengthen the recruitment of "Double employed academicians" and other high-level talents.

\section{The Training of High-Level Talents should be Independent}

As mentioned before, it is hard to recruit high-level talents. Thus, it is easier to train them independently. We can learn from Yangzhou University. One or two experts with great potential can be trained to be academicians. Our goal is to have academicians and Distinguished Young Scholars in 3-5 years or more.

\section{Talent Fund should be Promoted}

From 2008, we have implemented the "Top Talent" Fund and "Innovative Talent" Fund for 5 times. There are 32 and 50 these talents respectively in our university. They have been the academic leaders and key members in this university. Most of these 32 talents did with national projects. Their foundation items turned out to be successful. Thus, it is of great importance to vigorously advance the development of talents and high-level talents teams.

In the following times, we will spare no efforts to train more academicians and make the teachers in world level. At the same time, we will attach equal importance to the training and recruitment of talents with open preferential policies and good environment. In this way, a talent team with morality, high quality, proper structure and great energy will be formed to support the reform and development of school affairs.

\section{REFERENCES}

[1] The Cultivation and Development of School-running Characteristics of Regional Colleges and Universities, Zhong Haiqing, China Higher Education 2012.22
[2] The Way for Developing Regional Universities with High Quality and Characteristics under the Scientific Outlook on Development, Zhangqin, Education and Vocation, No. 2, Feb 2014 ( No. 786 in total) 